\title{
An Authentic and Generous Adult Educator: Peter Jarvis, 1937-2018
}

Peter Jarvis, who died on 20th November 2018 aged 81, was not only founding co-editor of the International Journal of Lifelong Education, but a theorist of adult education and lifelong learning whose influence has been felt in every continent. Two years ago we were able to publish a special double issue on his work and contribution: although already ill, he was delighted to be presented with a copy, signed by all the contributors, at his $80^{\text {th }}$ birthday celebrations in July $2017 .^{1}$

Peter sometimes said the he thought this journal his most important contribution. Not only did he cofound it (as Teddy Thomas recounts in his contribution below): he was one of our joint editors for 35 years. To mark his passing we invited a number of colleagues, from various spheres and geographical locations, who knew and valued Peter and his work to write a few words about him, taking their own personal perspective. We print these contributions below, followed by John Holford's address at Peter's funeral.

John Holford

Marcella Milana

Richard Waller

Susan Webb

Steven Hodge

[Figure 1: about here]

\section{Richard G. Bagnall, Professor Emeritus, Griffith University, Queensland, Australia: ${ }^{2}$}

\section{The Authenticity of Peter Jarvis}

I am moved here to reflect on the ways in which Peter Jarvis's scholarship on lifelong learning reflected his life's project as a lifelong learner. Central to Peter's conception of the individual human being was the lifelong search for existential authenticity in all aspects of one's lived experience: one's identity, morality, interests, commitments, projects, and relationships with others and with one's cultural traditions and expectations. Individual human existence itself he saw as the lifelong metaproject of creating one's own identity as a person through engagement in lifelong learning in an alienating cultural context in which one nevertheless necessarily experienced the realities that contributed to one's identity. Authenticity, then, involved being true to oneself in one's actions and being: individual integrity and consistency across one's projects. Lifelong learning, and the adult education that it embraced, was thus essential to individual (and collective) human existence.

Although he saw lifelong learning as being always grounded in individual experience (whether direct or vicarious), it importantly also involved individual reflection on its authenticity and hence its contribution to one's identity.

\footnotetext{
${ }^{1}$ The Learning Adult: Building and Reflecting on the Work of Peter Jarvis: International Journal of Lifelong Education 37(1-2). This Special Double Issue has since been published as a book: see Holford, Milana, Waller and Webb (2018).

2 r.bagnall@griffith.edu.au
} 
Peter developed and argued for that notion of the individual as a lifelong learner in his scholarly work - and he did so persuasively, with skill and flair - but my particular interest here is to reflect on the extent to which it also represented, and was represented in, his own individual publicly-evident identity. I take just four examples from that reflection. First, for Peter, one's experience underpinned one's identity. The richer that experience, the stronger the foundations of one's individuality. Anyone who sought to be as fully human as he or she could be therefore had a duty to him or herself to lead an experientially rich life. Peter's relentless immersion in studying social philosophy, spirituality, sociology and psychology pertinent to his quest for authenticity, and his unrelentingly exhausting commitment to being in different parts of the world in which he could enrich his engagement with other lifelong learners, may be seen as speaking to and reflecting this aspect of work.

Second, such engagements, though, were not trivial or superficially recreational, social or voyeuristic projects - even where (not infrequently) facilitated by eye-watering quantities of scotch whisky or good wine. They were, rather, matters of serious interpersonal exchange, proximate interpersonal engagement and discourse which he used to generate and extend his understanding of and empathy with others. I recall when Griffith University first brought Peter out to Brisbane as a keynote speaker for one of its early international conferences on post-compulsory education and training. In spite of my efforts to be traditionally welcoming, he eschewed any interest in the natural or cultural wonders of the 'sunshine state' in 'God's own country', in preference for serious discussion on details of his forthcoming presentation on the nature of ethics and the scholarly work in which I and others were engaged.

Third, Peter's notion of the authentic individual as a lifelong learner sees individual identity as strongly embracing a commitment to the welfare and wellbeing of others. Such a moral or ethical commitment is not, though, grounded in either tradition or rationality, but in the very nature of individuals as social beings. Responding to that reality demands of the authentic individual that he or she act in relation to others as fellow authentic individual lifelong learners with understanding, compassion and generosity. In that light, I note Peter's lifelong involvement in supporting and encouraging others as lifelong learners, through not only his academic work but also his many extremely generous material gifts - all made without any hint of self-gratification, attention-seeking, or reputation-enhancement.

Finally, here, I note that Peter's conception of the authentic individual as one whose public utterances and actions are always mindful that authenticity is a private and personal matter, albeit one with potentially profound public impact beyond oneself. Authenticity is to be lived, but not paraded. Authentic others may, or may not, see one as one sees oneself in anything like the same reality, but it is not for us to persuade them otherwise, except through our actions otherwise as authentic individuals. Peter, to those of us who were professionally close to him, was a very private person. While we valued what he shared with us, we recognised and respected the importance to him and his view of who he was as a person and of that which he held back.

In these and other ways, Peter appears to me to have been living the life of a truly authentic lifelong learner: living his own life's project through his experiences, the scholarly work of others on the human condition, and his engagements with others, but with critical deliberation, a concern for the welfare and wellbeing of others, and for the recognition that he was but himself. From my perspective he was a magnificent self, but I am confident that he would appreciate but not seek or expect that assessment. His life and his scholarship have much to say to those of us still standing in modernity. 


\section{Roger Boshier, Professor of Adult Education Emeritus, University of British Columbia, Vancouver, Canada: ${ }^{3}$}

\section{Bet Bacon on the Next Article: Dining High with Peter Jarvis}

As a child, Peter Jarvis was neither posh nor rich. His dad was a shipwright and definitely a working man. Peter was 8 years old when his father died in a road accident. Now Peter's mum was even more hard-pressed to put food on the table and shoes on young feet.

To help family finances, at the age of 10, Peter worked amongst milk, Sunday newspapers and tobacco racks at a local dairy. This was not fun and school was also an ordeal. Passing your A-levels was the way to transcend working-class constraints and make your solo mum happy. So when Peter failed his A-levels, his mum could only look at her son and sigh. But every problem has a solution and, in this case, it had two legs - adult education and Methodism.

At a nearby air base the Royal Air Force provided uniforms, there was a chance to march to a military band, hang around aircraft and do some flying. But English skies were disgusting and the way ahead was not clear. Peter endured the RAF from 1955 to 1958 but soon decided church was a better route to heaven. Hence, throughout the 1960s Peter was not a mod, rocker or teddy boy. Instead, he was a boisterous Methodist minister who had ideas about social justice and published in the Methodist Recorder. Sermons were the Jarvis specialty.

Fast forward to the 1980 and 1990s. It is early morning. Roger Boshier and Dan Pratt are looking through a glass pane in the door of the restaurant on the 4th floor of Caritas Bianchi Lodge in Kowloon, Hong Hong.

"Dan look, Brother Jarvis! He’s here. Talking about god knows what? Again!"

Reverend Jarvis was sitting at "our" table by the window. Outside there is rush hour tumult on Kowloon's Nathan Rd. There is also the famous Hong Kong stink. Hong Kongers say it's the smell of money.

This was not the first (or only) Vancouver hook-up with Peter Jarvis in Hong Kong. When someone offers an air ticket, accommodation and honorarium to the son of a shipwright, the answer is always "yes". Hence, Peter knew plenty about Kai Tak airfield.

We were all regulars at Bianchi Lodge and knew staff were trainees from mainland China. Now, the youthful waiter needs the order. Boshier and Jarvis are easily satisfied and will have eggs on toast. Pratt wants porridge, toast and a side order of bacon.

The waiter leaves for the kitchen, comes back, coughs and eyes Pratt.

"Err, um, sir, do you want that together?"

"Yes please," says Pratt.

There is a clatter of dishes, an extended pause and now, here comes three breakfasts.

Dan has thin toast on one plate and porridge in a bowl. Floating in the middle of the porridge is bacon - from a pig farm in Guangdong province, just across the border.

Next, there is uncontrolled laughing in church. Rev. Jarvis is chuckling. Chefs are looking through their peephole, pointing and giggling. Ha, ha!

\footnotetext{
${ }^{3}$ roger.boshier@ubc.ca
} 
Peter Jarvis clears his throat in a methodical Methodist way. He wants to speak to Comrade Pratt and points at the Made-in-China bacon.

"Professor Pratt," said Peter Jarvis, "there has to be an article in this somewhere!"

"Will you do it now or later?"

\section{Michael Crossley, Emeritus Professor of Comparative and International Education, University of Bristol, England: ${ }^{4}$}

I worked with Peter on the Editorial Board for the journal Comparative Education from 1991, when he first became a member. We guest edited two widely cited Special Issues on the state of the field at the turn of the millennium, and from 2003 to 2010 we worked especially closely together: Peter as Chair of the Board, I as Editor of the journal. Peter was a pleasure to collaborate with, he was always supportive and insightful and we shared much stimulating work, and many academic adventures and enjoyable Board lunches together. Peter's interest in comparative education was reinforced by his enthusiasm for international travel, his interest in learning from other cultures and worldviews, and his commitment to deeply human values and the empowerment of those marginalised in society at home and abroad. His work for our journal helped him to bring developments in the field of adult and continuing education in to the comparative arena, and in doing so he pioneered such multidisciplinary research and scholarship, often in collaboration with close colleagues and former doctoral students. While Peter was proud of his global recognition he was also well grounded in his local community, founding, for example, the Thatcham U3A in 2006 assisted by a small group of friends and his wife, and lifelong, supporter, Maureen. Peter will be remembered worldwide for his intellectual contributions but perhaps, above all, he will be missed for his respect for all things human and his international and cross-cultural network of enduring friendships.

\section{Trenton R. Ferro, Professor Emeritus, Adult and Community Education, Indiana University of Pennsylvania, USA: 5}

\section{My Memories of Peter Jarvis}

I feel as though I have lost a dear friend, although Peter and I had no direct contact for a number of years preceding his death. I first became aware of Peter's role in, and contributions to, the field of adult education when I was studying for my doctorate at Northern Illinois University where I used his work, The Sociology of Adult and Continuing Education (Jarvis 1985), for some papers and in preparation for my comprehensive exams.

I remember well my first encounter with Peter at the CPAE (Commission for Professors of Adult Education) meeting in Atlantic City in 1989 where we spent some time chatting during the reception. I was months into my first full-time position at Ball State and fully enjoying my conversation with this giant whom I had, up until this moment, known only through his writings.

After discovering that both of us shared backgrounds in pastoral ministry, we started scanning the room, pointing out others — not an inconsiderable number — who also were theologically trained and

\footnotetext{
${ }^{4}$ M.Crossley@bristol.ac.uk

5 trferro@yahoo.com
} 
had served in religious settings before becoming involved full-time in the field of adult, continuing, and community education. After the CPAE and AAACE (that was the time when CPAE preceded the American Association for Adult and Continuing Education meetings), Peter returned to Surrey, and I returned to Muncie, Indiana.

That, however, was not the end of the story. In his typical fashion, Peter, after returning home, put together a proposal to Krieger, together with his colleague, Nicholas Walters, for an edited volume whose contributors would all be adult educators who came from theological backgrounds - a direct result of that conversation and those observations in Atlantic City. Further, Peter's invitation to me, together with 18 others from Australia, Canada, the UK, and the US, to write one of the chapters in Adult Education and Theological Interpretations (Malabar, FL: Krieger, 1993) led to one of my earliest professional contributions.

I always looked forward to these professional meetings when the two of us, sometimes in the company of others, could reconnect and catch up on each other's personal and professional lives. Requiescat in pace, Peter!

\section{Brian Findsen, Professor of Education, University of Waikato, New Zealand: ${ }^{6}$}

My interactions with Peter Jarvis have been various but mainly in my role as an university-based adult educator. In particular, my work as a professor of (adult) education in a New Zealand university was the primary basis of my relationship with him. This is complemented by my work at the University of Glasgow from 2004-2008.

My personal/professional contacts with Peter were mainly at several SCUTREA conferences. I remember presenting about providers of adult education (principally in relation to later life education) using a well-known typology. At the end of the presentation Peter questioned me about whether the typology was as useful as I claimed and provided an alternative view. It was a critique undertaken in a challenging but pleasant manner.

In 1999, in mid-career, I undertook study leave from the University of Auckland, spending time at the University of Surrey in Guildford. We met at a Guildford pub and discussed the state of play of adult education in both our countries. Somewhat ironically, Peter was away overseas during much of my stay so I did not see him as much as I wanted, but I treasure the time I did spend with him.

Aside from these direct interactions, as an adult educator in this distant country I have used much of Peter's work with my Education students in which the theoretical breadth of adult learning/education has been ably demonstrated in his writings. As a latent sociologist of adult education myself, I especially valued his insights into social stratification linked to the practices of this field. As I now cast my eyes over my personal adult education collection in my University office, Peter's extensive knowledge emerges through the many books he wrote, complemented by on-line versions of his work.

In 2015 Peter invited me to act as a guest editor for the IJLE for a learning in later life edition. This surfaced in the volume 35, issue 5, 2016, and has just been made into a book, Fresh perspectives on later life learning, published by Routledge (2019). This gesture is typical of Peter's support of people such as myself in terms of unselfishly promoting other persons' careers and allowing new

\footnotetext{
${ }^{6}$ bfindsen@waikato.ac.nz
} 
perspectives of a sub-field of adult education to emerge. I am hopeful that Peter's legacy will live on in this part of the world.

[Figure 2: about here]

\section{Patricia Gouthro, Professor, Graduate Studies in Lifelong Learning, Mount St. Vincent University, Halifax, Nova Scotia, Canada; a former joint editor of the International Journal of Lifelong Education: ${ }^{7}$}

It was during my doctoral studies that I was first introduced to the International Journal of Lifelong Education. This was before I became a professor, before I travelled to Australia, the UK and Europe, before I taught in Jamaica for a dozen years, and before I met many different colleagues I have come to know over the years who live and work in different parts of the globe.

This journal was an important part of my introduction to the diverse range of scholarship and research happening in the field of adult education and lifelong learning. As I developed as a scholar, publishing in this and other journals, and then working with Peter and John as a co-editor of the journal for two years, I continued to be amazed at the wide range of research shared through this publication. Much of the credit for the global interest and recognition given to the journal can be linked to the enduring commitment that Peter had for this work. When I came on board, Peter was just overseeing special editions, while John and I handled the review process for the dozens of articles that were submitted for regular volumes. During this time, however, I had enough meetings with Peter (mostly by phone) where I came to recognize his passion for the field, and his lively interest in adult education projects that were occurring across the globe. Many of the people I met in connection to the journal told me stories of how they had been encouraged to submit their work by Peter. Peter was quite proud that through the journal he was able to offer a space for emerging scholars, for women, and for academics working in nations in South as well as the North, to share their work with readers across the world. Peter was committed to maintaining academic rigour, but if an article was submitted from a country that little research had been published on, he was always regretful if it didn't pass the review process. He loved the idea that through the journal a voice could be given to many scholars who otherwise would not have the opportunity to disseminate their work to such a broad audience.

Peter was an academic who had a very extensive knowledge of the field, and I learned a lot from him about how to get to the essence of an article when offering critique. He accepted that sometimes the work involved hard decisions, but he was courteous and thoughtful in his responses. He has left behind a team of excellent scholars who will carry on his legacy and help the journal continue to evolve in response to a changing field, but I am pleased to share a few words to acknowledge the important contribution that he made to adult education through his work in founding the International Journal of Lifelong Education.

\section{Shibao Guo, Professor of Education, University of Calgary, Alberta, Canada: ${ }^{8}$}

Peter Jarvis was a visiting professor of the University of Calgary for two weeks in July, 2008. During his visit, he delivered a keynote speech at the Summer Institute, taught a graduate course in lifelong

\footnotetext{
${ }^{7}$ Patricia.Gouthro@msvu.ca

${ }^{8}$ guos@ucalgary.ca
} 
learning, and helped us launch the Doctor of Education program in Workplace and Adult Learning (WAL). As the WAL Specialisation Coordinator, I hosted his visit. I had the great honour and pleasure getting to know Peter well at a personal level from this visit. The Summer Institute where he gave the keynote was an annual event at our faculty, which attracted 150-200 people, including our own graduate students and participants from the surrounding education communities in Calgary. His keynote speech at the institute was followed by informal conversations with the participants which enriched their learning experiences. He was so accessible which made everyone feel comfortable to approach him and have an inspiring conversation about lifelong learning.

The course he taught, Lifelong Learning and Learning Society, was a 3-credit graduate course, which enrolled both master's and doctoral students. Based upon a multi-disciplinary analysis of learning and the learning society, the course examined theories of human learning which showed that it is both an existential and experiential process. The second part of the course consisted of a sociological analysis of the knowledge economy in which globalisation, the information society, lifelong learning, and the learning society were analysed. Consequently, the final part of the course assumed a political and ethical orientation and the course concluded by suggesting that there was a need for a revolution in learning. In the course outline, he states: "Understanding the learning society is a sociological exercise in which power is a covert but ever-present phenomenon generating certain emphases which are frequently presented as the natural outcome of society, so that participants will become more aware of the way in which global capitalism functions through the ideas of lifelong learning and the learning society." Our students really treasured the opportunity of learning with Peter. They felt that they were learning with a real sage in adult education, which best captured how students felt about Peter and their learning experiences.

During this visit, I also had the opportunity to show Peter around Calgary and the sounding areas. We attended the Calgary Stampede Parade and Chuckwagon Races. We visited the beautiful Rocky Mountains. We also went to Drumheller to see dinosaur exhibits at the Royal Tyrrell Museum. Peter always showed appreciation of all the arrangements, which he genuinely enjoyed. When we were together, we also had many engaging conversations about lifelong learning. During the second weekend of his visit, I remember I took him to visit the Rocky Mountains. It was absolutely a gorgeous day with blue skies and clusters of white cloud. The temperature was comfortable. When we drove into Moraine Lake, we were surrounded by trees and glacier on top of the mountains. After we parked, we had a nice stroll around the lake. We walked about 15 minutes into the forest and then we stopped. We sat down on a bench for about 10 minutes. Facing the beautiful lake and glacier, Peter was stunned by the view and the peaceful and quiet atmosphere. He became quite excited and emotional. Then we had an amazing conversation about emotional learning. We also talked about the surrounding environment and environmental sustainability. It was a memorable moment for him and for me. He said he would document that in his next book.

I kept in close contact with Peter after his 2008 visit. I learned a lot from the interactions with him. I also appreciate all his support and mentorship. It is hard to believe Peter is now gone. He will be deeply missed, but his scholarship will continue to inspire scholars all over the world. 


\title{
Budd Hall, Professor of Education, University of Victoria, British Columbia, Canada; Co- Chair, UNESCO Chair in Community Based Research and Social Responsibility in Higher Education; formerly Secretary-General of the International Council for Adult Education: ${ }^{9}$
}

I first met Peter at the gathering of the American Association for Adult and Continuing Education meeting in Washington DC around 1987. I was the Secretary-General of the International Council for Adult Education at the time. Peter had set up a booth in the publications area of the Hilton Hotel where the conference was being held. He had brought several suitcases of books on adult education that had been published in England, but were either not known in the USA or not available. It is hard to imagine these days when books are instantly known and are available, for a price, via the various internet sites, but in 1987, very few US adult educators would have seen books written in the UK by UK authors. In speaking with Peter, it seems that he came up with the idea himself. If the 1000+ members of the AAACE met annually, it was quite simple to bring copies of books to those meetings and strengthen the international intellectual foundations of our field. Peter was not yet the prodigious scholar that he was to become, but he was pleasant, out-going and interested in what younger scholars in the US were interested in writing. His practical approach to internationalism played an important role in building what was to become a much closer connection between UK and US adult educators.

I shared many international conferences with Peter as he had a love of travel that was almost as strong as his love of writing. In addition to serving as a terrific Editor of the International Journal of Lifelong Education, and author of scores of books, he also served as an Editor of many of the encyclopaedias that chronicled the intellectual evolution of the field of adult and lifelong education. I contributed to a number of his encyclopaedia projects sometimes writing on subjects that I was not really a specialist in. He was always encouraging saying that he was sure that what I would write would be excellent.

Perhaps the most wonderful story about Peter happened a few years ago when I was visiting my friend George Openjuru, the new Vice-Chancellor of Gulu University in Northern Uganda. George took me to visit the new University library that was under construction. He took me to a space with as yet no roof, but of ample size and said, "This is where we will put the Peter Jarvis collection of adult education books". "What do you mean", I asked, "Which books are you speaking about?" George replied, "Peter has donated his entire collection of books, books of his own and the many others collected over the years to Gulu University. They are being shipped here from England". George, who is also an adult educator has agreed to inaugurate an adult education programme at Gulu University and the Peter Jarvis collection will provide Gulu students with the best collection of adult education books perhaps anywhere in Africa. The last I heard was that the University Library at Gulu University in Northern Uganda has been finished with Peter's collection in pride of place.

\section{Dawn Hillier, Managing Director of Accomplishing Wellness Ltd and Principal Consultant of Strategic Change Partnership; previously Dean, School of Health Care Practice, Anglia Polytechnic University (APU): ${ }^{10}$}

\author{
Inspiring, challenging and kind
}

\footnotetext{
9 bhall@uvic.ca

${ }^{10}$ dawnhillier@yahoo.co.uk
} 
I was very fortunate to have Peter as my supervisor throughout my University of Surrey journey. I arrived at Surrey as a mature student having just gained an Advanced Diploma in Midwifery. For the first time I was going to experience university life. I was studying for my Midwife Tutor's Diploma which was linked closely with the Post Graduate Diploma in Adult Education. I was a naïve and frightened woman. I was not at all sure that I could be successful. Then Peter Jarvis was assigned as my mentor/supervisor. What a revelation. He opened a whole world for me. I was studying the education of adults, sociology and philosophy of education - he introduced me to writers such as Paolo Freire who 'blew my mind'. Peter encouraged me to develop my teaching skills using his own sensory learning theory that focused on the process of learning through social experiences. This was particularly significant in my field of midwifery and henceforth formed the basis of my teaching and learning career. It also formed the foundation of my doctoral research driving my ambition to seek out real lives and real stories that people share. Following Peter's example, and under his guidance as my doctoral supervisor, I travelled the world learning through social and cultural experiences. He introduced me to a number of inspiring and challenging people. Without Peter's belief and encouragement I would never have published, spoken at conferences in different countries and gone onto the academic success I achieved. I owe Peter a great deal and I will be eternally grateful to him.

\section{Cheryl Hunt, University of Exeter, UK; Chief Editor, Journal for the Study of Spirituality: ${ }^{11}$}

'We are separate from our roles and, although we identify ourselves with them, our personalities transcend them - we do things "our way". ' (Jarvis 2009: 204).

The roles Peter Jarvis played in his life were numerous, his personality was a charismatic one - and he undoubtedly did things 'his way'. It was a way that had learning at its heart, his own and how it might be encouraged in others.

I remember hiring a taxi with him during a free couple of hours in a conference in Belfast: we wanted to see some of the murals and to find out more about life during 'The Troubles'. We almost missed the conference dinner because Peter, always a great conversationalist, encouraged our driver to tell us stories, take us to places, and provide information that went far beyond the normal tour agenda. After dinner, in the late-night bar, Peter delighted conference colleagues with the story of our taxi adventure. It was much embellished and elicited a great deal of laughter - but never once lost sight of the tragic circumstances and cultural issues that underpin the murals themselves. Sharing knowledge, expanding it, always finding the humanity in it - and as much laughter as possible - that was Peter's way.

It was a way that he took into his role as an editor and I, like many others, am indebted to him for the manner in which he played that particular role. It is essentially a gate-keeping one but, for Peter, it was about opening the gate wide rather than trying to keep people and/or certain forms of writing out. Always an educator, when other editors would probably have sent a rejection letter, if Peter felt that inexperienced authors had something important to say he would spend time showing them how to overcome shortcomings in their writing. He opened the gate for my own writing on spirituality at a time when the topic was struggling for a foothold in academia.

Many years later, over breakfast at another conference on another continent, I had a discussion with Peter and a few other colleagues about the need for an inter-disciplinary, interprofessional journal to

${ }^{11}$ C.Hunt@exeter.ac.uk 
bring together work on spirituality that had by then begun to emerge in a number of different disciplines. Peter's support and encouragement were instrumental in bringing the Journal for the Study of Spirituality into being. The journal is now entering its ninth year of publication. Peter was a member of the Editorial Board until his death: his reviews were always constructively critical and supportive. And his 'way' lives on as I try to emulate his editorial style in keeping open a gateway to the study of spirituality. The field of 'spirituality studies' is as difficult to define as that of 'adult education' but Peter's way led through both - and both are the better for that.

\section{Dr. George A. Koulaouzides, Thessaloniki, Greece: ${ }^{12}$}

\section{A few lines for Peter}

As I am writing these lines, I still have not fully accepted the fact that Peter Jarvis has left this world. Since this text is more of a personal account, I will share a few memories from our relationship. The ones that come to my mind as I am typing. So, my first contact with Peter was rather official. It was back in 1995 and I had just started my studies at the University of Surrey, participating in an innovative postgraduate programme which was offered from Peter's department. I live in Greece, and the opportunity to study from a distance was for me back then, an educational oasis. But I was inexperienced in this new mode of learning and either from anxiety or because of lack of personal discipline I had misunderstood the very first assignment... and Peter was evaluating! When I realized my mistake, it was too late. I was depressed. The paper was mailed by post and it was impossible to take it back. Thus, I was expecting the news and a failing grade. When the response arrived, I opened the envelope and I saw more than a simple mark... You see, Peter had read the whole of my "wrong" work and made full comments. In the end, he invited me in a kind and friendly way to resubmit the paper pointing out my good points. Peter had gently "rejected" my paper, but he had not rejected me. Coming from an inflexible and impersonal academic environment like the one that exists in Greece, Peter's evaluation was more than a second chance, it was a life event. Later, I managed to save money and travelled to the UK to attend an intensive weekend course. During one of the breaks, I practically bumped into Peter. I felt awkward, but his smile was so kind that I went on and introduced myself and he invited me to join him for lunch. That was it...We spend more than an hour together discussing issues related to education, politics, religion but also laughing since his sense of humor was astonishing! That moment a friendship was born. Shortly after my graduation I asked Peter to come to Greece and support our effort to develop an adult education scientific association. He gladly accepted my invitation and he visited Greece not once but more than a dozen times. Everywhere and anytime we were asking for his contribution Peter was available for us, full of energy, academic brilliance, humility and humour. He gave lectures, but we also travelled together, tasted new wines and food from all over Greece, visited the Holy Mountain, the Meteora Monasteries, the tombs of the Macedonian Kings and other sites. Peter was a world citizen, always open to meeting new people, listening and to sharing. If the field of adult education in Greece is nowadays vivid it's because Peter supported our ideas and efforts with all his heart. Peter was a remarkable person, a unique teacher, a loyal friend and my life and the life of many other friends here in Greece was illuminated by his spirit and good heart. He will always have a central place in our heart.

\footnotetext{
12 koulaouz@otenet.gr
} 


\section{Chandra Laksamba, Senior Researcher, Centre for Nepal Studies UK: ${ }^{13}$}

Peter was a thinker, as well as a strong believer in and advocate of adult and continuing education. $\mathrm{He}$ saw adult education as pivotal in creating and transforming "experiences into knowledge, skills, attitudes, beliefs, values, senses and emotions" (Jarvis 2001: 10), and for expanding education for people who had limited learning opportunities in early life (Jarvis 1995). I consider myself as an example of this: I am an ex-Gurkha soldier with 19 years' experience in the British army, but I had little or with no academic knowledge and very limited opportunities for further and higher education. Despite these difficulties, with Peter's skilful supervision, guidance and encouragement, I achieved a $\mathrm{PhD}$. As I wrote in the thesis,

"I remain ever in debt to Professor Peter Jarvis, my principal supervisor for his patience, tireless motivation and sagacious guidance in moulding and enabling this Gurkha soldier from the hills of Nepal to fulfil his dream of becoming a Doctor of Philosophy. I express my sincere, heartfelt gratitude for all his valuable suggestions, supervision and untiring efforts in guiding me to complete the study, without which it would not have been possible." (Laksamba 2005: xviii)

Peter had immense experience, knowledge and skills in adult education and in guidance to adult learners. As he wrote, “... all learning stems from experience” (Jarvis 2001: 46),, adding that “... learning always occurs within a social context and that the learner is also to some extent a social construct, so that learning should be regarded as a social phenomenon as well as an individualistic ..." (Jarvis 1987: 15). Peter was also deeply interested in globalisation, lifelong learning and its impact on society.

Peter was an advisor of the Centre for Nepal Studies UK (CNSUK) from its inception in 2006. It was Peter who suggested CNSUK carried out survey research on Nepalis living in the UK. In 2009, based on this research CNSUK was successful in securing ESRC and AHRC large scale research funding in collaboration with the University of Oxford. Further, CNSUK did research on the equal rights of Gurkhas, social mobility, and so on, for which Peter always made himself available for advice. In addition, Peter went to Nepal in 2007 along with a team from the CNSUK . He met Chairman Prachanda and Dr Baburam Bhattrai of the Communist Party of Nepal (Maoist) and gave advice on transforming Maoist Militias' and People Liberation Army's (PLA's) experiences into knowledge and skills. At the time of the visit, the Maoist rebels were at the negotiation table after the 10-year long revolution. More than 20,000 Maoist Militias and PLAs were in barracks across the country, awaiting integration in the armed forces, public service and civil society. The Maoist leaders highly appreciated the advice and applied it during the process of integration.

\section{Dr Alison Le Cornu, Consultant in Academic Practice; Honorary Research Fellow, Queen's Theological Foundation, Birmingham, UK; formerly Academic Lead for Flexible Learning, Higher Education Academy (UK): ${ }^{14}$}

"Yes, happy to meet you" the voice at the other end of the phone said. "Can you come to Waterloo station for 1 o'clock? I'm in transit. Meet under the clock on the forecourt. I'm easy to recognise; I have a shock of white hair."

\footnotetext{
13 claksamba@gmail.com

14 alison@alisonlecornu.co.uk
} 
So began my 25 years of studying under, working with, learning from and being influenced by Peter. We quickly hit it off; his gregarious nature and keen mind took me to places I'd never dreamed of, both professionally and intellectually, giving me confidence as well as, on occasion, acting as confidant. He became a genuine doktorvater, a 'doctoral father' as his thinking and intellectual explorations came to underpin my own; yet as I learned his - our mutual - trade, he was gracious in being challenged and generous in acknowledging my own contribution to his work.

The core of our relationship lay in his religious background and ongoing engagement with theology as a discipline and the practical outworking of adult theological or religious education. His edited volume Adult Education and Theological Interpretations (1993) remains one of the 'go to' texts for many in the field, practitioners and scholars alike, appreciated for its down to earth pragmatism and unashamed theological liberalism, the combination of which offered a way forward to those who wanted to hear and to think about their faith. Peter never lost his faith, although he constantly modified it to the point that to some it was barely Christian and indeed barely faith. Typically, this bothered him little. His mission was to pursue, explore and understand more profoundly what it means to be human, in relation to a higher being and within a constantly changing social context. No sources were excluded from this endeavour, no thinkers dismissed out of hand, no experience deemed irrelevant. Yet Peter subjected them all to a robust analysis and evaluation, able to re-appropriate insights from the most unlikely of places and weave them into his understanding of the human condition. This, above all, was the over-riding focus of his interest, and as a result a large number of his works, ostensibly about learning, are strongly religious in nature.

His legacy to me? I became comfortable challenging many of the basic tenets of the Christian tradition. I gained skills and understanding that took me forward professionally. I found a longstanding friend and colleague. Above all, I began my own journey of learning to be a person (of faith) in society.

\section{Balázs Németh, Associate Professor in Adult and Lifelong Learning, University of Pécs, Hungary; founding member of the Hungarian Universities Lifelong Learning Network (MELLearN): ${ }^{15}$}

\section{Remembering an Outstanding Scholar who Connected Theory and Practice in Adult Learning}

Peter Jarvis was a passionate lifelong learner on his road of learning. Moreover, he really was a gentleman in trying to understand learning with devotion in and outside classroom worlds. He felt at home both in the university classroom environment and amongst adult learners of community centres and of third age movements. He not only influenced the formation of emerging national and European policies around lifelong learning, but vigorously asserted the necessity of paying attention to formal, non-formal and informal learning with a complexity of analysis and reflection. His concept of adult learning, more precisely, the 'Jarvis model of describing adult learning' has achieved a particular respectedly place amongst theories of adult learning.

Peter was one of the few intellects who insisted on connecting the matters of employability with those of citizenship, therefore, he loudly stood for the expansion and the strengthening of active citizenship in communities of learners. Amongst many other quality books, his trilogy on lifelong learning clearly signalled his alliance with human dignity, equity and critical mind. Peter, as he liked to be called, was

\footnotetext{
15 nemeth.balazs@pte.hu
} 
arguing for a rather balanced view on lifelong learning and reminded both his readers and audience that lifelong learning was more than a simple term, that it would need attention and care towards the learner with courage and vision to bring change and hope to vulnerable groups and communities through adult education and lifelong learning.

Peter underlined the responsibilities of adult educators and researchers in the development of scientific advancement of the field and claimed more focus on the development of adult learning professionals. In this respect, one can never forget the power, the engagement and a gentle collaborative style and curiosity with which he constantly engaged in the organisation of conferences, international projects, research activities and analytical work in order to move in theory and practice of adult learning forward and, likewise, to provide particular narratives upon adult and lifelong learning with accuracy and academic care.

Peter never believed in the power and short-term victories of political or ideological hegemonies, nor did he accept limitations to adult education and or adult educators. In this respect, he provided excellent examples of making and developing connections, linkages and, moreover, friendships amongst scholars, researchers of adult learning and education from various universities across Europe -his way of uniting Europe and other parts of the world. Peter believed in the power of co-operation rather than conflict, he emphasized dialogue between cultures rather than top-down statements and declarations, and this became his mission when he moved to some remote place of another continent to collect and share good ideas around adult learning and education. Paradoxically, it was Peter who brought young scholars in lifelong learning in Romania, Serbia, Slovenia, Austria, Hungary, Croatia, Poland, Estonia, Lithuania, the Czech Republic, etc. to collaborate and to work together in the field of adult education by making use of emerging European funds, like that of Grundtvig.

I can easily recall many conversations with Peter, in Guildford and in Pécs. He always stood for the involvement of several disciplines in the description and the understanding of lifelong learning and education, but reminded us not to forget the role of critical thinking in adult education. At a time when there is a wave of bringing attention to the thought of Paolo Freire, one should not forget that it was Peter who consciously connected the thought of Freire with his concept of lifelong learning in order to explain why the learner should be put into the axis of reasoning. Like Freire himself, Peter carefully explained why a dialogical approach is essential in making learning effective.

I remember one occasion from late winter of 2003 when Peter proudly took me to a U3A event where he was lecturing to older adults on adult and lifelong learning. At the end of his lecture he took one of the U3A Magazines and called my attention to the headline, expressing his strong agreement and support and quoting loudly:

\section{'Learning is for life and not just for jobs!'}

That is how I will proudly keep him in my heart and mind, and recognise that his thoughts will always stay with us when we try to build on his virtue and principles.

\section{Michael Newman, formerly of University of Technology, Sydney, author of many books including The Poor Cousin (1979), Defining the Enemy: Adult Education in Social Action (1994), Maeler's Regard: Images of adult learning (1999) and Teaching Defiance (2006):}

Peter played a significant role in my professional life. He was both mentor and personal friend. In the late 1980s, I was busy trying to convert from a trainer with the Australian Trade Union Training Authority to a Senior Lecturer in Adult Education at the University of Technology, Sydney (UTS). 
We were in his living room and he stood, which he seemed to do when he had something important to say, and pronounced: "These are the books you should be reading, Mike." I asked him to repeat the list, noted the books down, and bought as many as I could find in the university bookshop the next morning. One of them had "perception" in the title, and it was an example of the way Peter quietly guided me. What, after all, were we doing if not helping people "see" more clearly. What, after all, were we doing if not making people more conscious so that they would be able to see things more clearly? Vale, mate.

\title{
Elizabeth Oliver, University of Surrey, 1969-72 and 1979-2006: ${ }^{16}$
}

I worked as an administrator in the Department of Educational Studies of the University of Surrey for some 25 years, and for much of that time Peter was one of my closest colleagues both as Head of Department (1993-1996) and as Director of the Department's distance learning course in the Practice of Education. This course was offered at Postgraduate Diploma and Masters level to those teaching in adult, continuing and higher education; many of the students went on to study for doctorates under Peter's supervision. Distance learning was then still somewhat in its infancy but we were able to offer the programme on a worldwide basis and we both firmly believed that the role of course Director and Administrator should involve establishing a personal rapport with the students be they be based locally or in far flung parts of the world. Peter, of course, was able to visit many of the latter on his travels.

Peter's period as Head of Department coincided with University-wide restructuring but at all times he kept the interests of his staff and students to the fore. When the Department's focus moved to Political and International Studies, he ensured that those who had enrolled on education courses were fully supported.

It was a privilege to work with Peter and to absorb his enthusiasm for adult and lifelong education. I was able to maintain a friendship with him and his wife, Maureen, long after we had both retired and I will always be grateful for this.

\section{Michael Omolewa, Emeritus Professor, University of Ibadan, Nigeria: ${ }^{17}$}

\author{
Good Night, Peter
}

We were not prepared for the news of the transition of Peter Jarvis, a household name in Africa in the broad field of adult and continuing education.

Peter was a master when it comes to making a person feel welcome, confident and satisfied with living. It is likely that his Methodist upbringing had much influence on how this scholar, teacher, researcher and global academic perceived things. He saw the Living Jesus Christ in people. Like Saint Paul who explained that he was all things to all men to ensure that his message got across, Peter was willing to break all protocol to get his message across to everyone, at all levels of academic pursuit, religious affiliation, age, race and social background. Long before the United Nations adopted the Convention on cultural diversity, Peter was already operating the spirit of the Convention.

\footnotetext{
${ }^{16}$ elizabeth@gandeoliver.co.uk

${ }^{17}$ michaelomolewa@yahoo.co.uk
} 
The University of Ibadan in Nigeria benefitted from the compassion of Peter, as he demonstrated his tolerance and sensitivity. He once made the sacrifice of travel to Nigeria to attend the international conference on adult education hosted by the Department of Adult Education of the University of Ibadan, Africa's oldest Department of Adult Education, in spite of threats and reports of insecurity during the military rule in the country. His participation at that conference inspired many colleagues to adopt adult education as a field of study in the University. He radiated warmth as he identified several uses of the subject of lifelong learning. He encouraged academics to submit articles to the prestigious International Journal of Lifelong Education, and he patiently waited for several reviews of manuscripts which later got published. His perseverance and passion to help other younger academics also led to the publishing of articles of colleagues from the University of Ibadan on exchange visit to the University of Nottingham as part of Higher Education Development programme supported by the British Council.

He later invited me to serve on the editorial board of his journal, accommodating the various changes in my address as I moved from the University of Ibadan to serve as Nigeria' Ambassador to UNESCO in France, and back again back to Ibadan to resume teaching, research and community service. He was no doubt delighted to see me among those who had travelled to the University of Nottingham to be part of the celebration of the much deserved award of honorary degree to him. I was proud to be associated with him.

We will forever miss Peter the visionary and bridge builder. We are glad that his footprint in the sand of adult education is permanent. I pray for our reunion on the Resurrection Day. He was a good and great man and scholar. May his entire household be thankful that his pains are gone as he sleeps on in peace; and may they be consoled.

Good night.

\section{George Ladaah Openjuru, Professor and Vice Chancellor, Gulu University, Uganda: ${ }^{18}$}

\section{Professor Peter Jarvis and his last visit Uganda}

I am not sure if I am qualified to write this eulogy about Peter Jarvis. He was such a towering figure of eminence in the field of adult and lifelong education, in comparison to whom I am little more than a novice. Nonetheless I had the privilege of interacting with him, when I got the opportunity of inviting him to grace a Regional Conferences on research in Adult Education in Eastern Africa (Ethiopia, Uganda, Kenya, Tanzania, Rwanda and Burundi), which Uganda was organising with financial support from the German Adult Education (DVV/IIZ) 16th-20th November 2009. In spite of his very high stature in the field of adult and lifelong education he agreed to come and present a paper. He came as Keynote Speaker, together with Julia Preece from South Africa, another great name in Adult and lifelong Education in Africa who linked us to him. The presence of Peter Jarvis at the conference elevated the status of the conference immensely.

One unforgettable and possibly regrettable experience is that when I was picking him up from Entebbe Airport in my old car, we had a tyre burst on our way back to Kampala, forcing us to wait for the tyre to be replaced by the driver in the middle of the night. That was not a very good welcome on his first and last trip to Uganda. What struck me was how he took it so calmly.

\footnotetext{
18 g.1.openjuru@gu.ac.ug
} 
While in Uganda, I recall how his presence generated a lot of excitement among staff and students of the then Makerere University Institute of Adult and Continuing Education (IACE; now the School of Distance and Lifelong Learning). Many of us were seeing him in person for the first time and, I am sorry to say, the last time - he never came back again. Before his visit the eminent scholar was more known as an author of adult education books. Taking advantage of his visit, we requested him to give a talk to students and staff of IACE.

Most important to Uganda was Peter's most significant, memorable and generous donation of the whole of his book collection to Gulu University in Northern Uganda to support the establishing of the department of adult education and lifelong learning. Gulu lies in an area which has suffered over 20 years of military insurgence at the hands of the Lords Resistance Army (LRA).

These books are going to be used not only in laying the foundation for the new department but also for stocking the new library block in the university. I can say this was one of his last wishes. I felt very emotional seeing a photograph of him in hospital, with the photo of the new library building by his bedside. It is painful and unfortunate that we have not been able to complete the library while he was still alive. Although this is not yet concluded, we are most likely going to name the library after him in recognition of his generous love and book donation to Gulu University. We shall have this as a special collection of the work of Peter Jarvis. I see this as his last gesture in the promotion of adult education and lifelong learning to which he had dedicated his life as a scholar. May the work of his hands continue to be blessed.

\section{[Figure 3: about here]}

\section{[Figure 4: about here]}

\section{Stella Parker, Robert Peers Professor of Adult Education Emeritus, University of Nottingham; formerly joint editor of the International Journal of Lifelong Education: ${ }^{19}$}

Peter has gone but for me he will not be forgotten. His legacy includes not only his impressive collection of scholarly publications but also the memories I have of him.

I first met Peter at a conference in the mid-1980s. He was working then at the University of Surrey and had already established a national and international reputation that drew the crowds to his seminar. I was unable to attend his seminar but later I met him in the bar. He was good company; amusing and erudite and clearly totally committed to his academic field.

A few years later I worked with him as part of a team on several projects, including a series of workshops in South Africa. He was a delight to work with and an inspiring teacher, more so because he based his teaching on his research. During the week or so we spent together in South Africa, we travelled by car to a number of locations. Peter was always eager to stop for 'refreshments' around mid-day, and as soon as we entered a service station he would disappear. The first time this happened, I bought a coffee and waited for him to reappear. My modesty initially prevented me from searching for him but eventually, out of curiosity, I went on a tour of the service station. I found him in the bar

\footnotetext{
19 stellaparker2016@gmail.com
} 
area, glass in hand watching the sports results on television and talking enthusiastically with others there. He later told me he liked to keep up with the sports results wherever he went and televisions in bars were good places to do this - and (he said) he met interesting people in bars. Meeting people and talking to people were two of his delights.

I was privileged to work with him on the editorial board of the International Journal of Lifelong Education, of which he was a founding editor. The journal's reputation is now well established and Peter's humanity drove him to take what some might regard as risks by publishing contributions from those with less established scholarly reputations. Editorial board meetings were demanding and intensive morning sessions that were lightened by the prospect later of an excellent lunch served with good wine. Peter always enjoyed these lunches.

My memories of Peter are of a bon viveur - someone who loved life, who loved to eat and drink, who was amusing and interesting and, because of his respect for others, could mix easily with people from many backgrounds. A kind man, a gentle man, who contributed outstandingly to his academic field.

\section{Julia Preece, Professor of Adult Education, Durban University of Technology; Honorary Professor of Adult Education, University of KwaZulu-Natal \& University of the Free State, South Africa: ${ }^{20}$}

Peter, like so many of us in the adult education field, came into academia via a circuitous route. I am sure this experience influenced his commitment to the social purpose agenda for adult education and also his commitment towards emerging scholars. I knew of Peter long before I met him, but when I finally did so in a new lecturer post at Surrey University very shortly after completing my $\mathrm{PhD}$, I was immediately captured by the intellectual stimulus that he provided through informal lunchtime get togethers as well as the opportunity to engage with international scholars in more formal seminars and, along with the hard efforts of his colleague John Holford, international research projects. It was perhaps the most intellectually stimulating time that I have ever had as an academic. Soon after I arrived at Surrey, Peter willingly read and then provided the preface to my published doctoral thesis, my very first, authored book publication. He then supported my efforts to come to Africa where I have since spent the greatest part of my academic life. He came out to visit me twice when I was working in Lesotho, using his own funds on both occasions, inspiring local university students to think critically and never give up. He was keen to create opportunities for African writers and, in 2011, enabled a special issue ${ }^{21}$ of the International Journal of Lifelong Education to feature African authorship to this end. His generosity in supporting academics in under-resourced parts of the world was a defining feature of his engagement with Africa. This is evidenced by his equally self-funded trip to a workshop in Uganda which I also attended and his subsequent donation of his own enormous library of books to the University of Gulu in Uganda. Additionally he arranged the transfer of a substantial sum of money to the National University of Lesotho that could be used as prize money for outstanding Masters students studying adult education, even attending the graduation ceremony of the first student to benefit from the prize.

\footnotetext{
20 juliap@dut.ac.za

${ }^{21}$ Lifelong Learning in Sub-Saharan Africa (guest editors: Julia Preece \& Catherine Odora Hoppers): International Journal of Lifelong Education 30(1).
} 
Aside from being a prolific writer and inspirational thinker in the field of adult education and a few other disciplines on the way, Peter was a unique individual, kind and generous with his time, money and energy to promote and support other scholars. Even during his ailing last few years, he continually counted his blessings in having had the opportunities to travel, gain friends from around the world and contribute intellectually to the scholarship of adult education and lifelong learning. $\mathrm{He}$ wanted his contributions to last beyond his lifetime and he has indeed ensured that will happen in so many ways in so many parts of the world. This was a life well lived and it will be well remembered.

\section{Dr Vida A. Mohorčič Špolar, University of Ljubljana, Faculty of Arts; Former Director of the Slovenian Institute for Adult Education: ${ }^{22}$}

\section{Peter Jarvis, a supervisor, teacher and a friend}

Until 1992 the name Peter Jarvis meant nothing to me. I did not know him since my work area before that time was a different one. Adult education and andragogy was a subject of my study within my second university programme, while research-wise somewhat later while working on my dissertation. In 1992 Peter Jarvis was just one the name of one of my supervisors who undertook this role in my doctoral studies within the European Union's TEMPUS programme.

When I talked with people working in the education of adults in England I discovered that their opinion of Peter Jarvis varied. For some he was an expert on the education of adults for others somebody who was only learning about it. In this context the sentence most often heard was: "What Peter doesn't now he writes about."

And then I came to the University of Surrey, Guildford and met him. He was unbelievably dynamic, hardworking, open, friendly and proud of his students. He knew where everyone was, what they were involved in and in what they excelled. He used to say that he was a very contented man. He said he was blessed because he had so many friends.

Somebody wrote that Peter had a problem saying no to a paid airline ticket. There is certainly some truth in this. Peter liked lecturing, asking provocative questions and enjoyed in the discussion that developed. He liked to travel. Travelling rendered it possible for him to look into different countries, cultures and various systems of the education of adults. He liked to discuss that, he was inquisitive and asked a lot of questions. He internalised all this, thought it over, reflected and started looking anew. In this context the sentence "What Peter doesn't now he writes about" has a very different meaning. It sounds a challenge. He was curious, he wanted to know. If he wanted to know he had to ask, research, read, discuss, lecture, receive feedback, create .... And he created so much. When he could he wrote every day, almost the way Ernest Hemingway did. If he did not write anything the day was lost to him and he had to compensate for it. But towards the end this was not possible any more. Writing, which he enjoyed the most, was denied to him.

The man who was a Methodist minister and who prided himself that he was still serving, the man who wrote dozens of books and co-founded the International Journal of Lifelong Education became silent. As Linden West wrote: "He represents a generation that was deeply committed to a dialogical adult education, as the basis for the better world. The best tribute we can pay is to continue the struggle in our present dystopia."

\footnotetext{
22 vida.mohorcic-spolar@guest.arnes.si
} 
But there will not be dialogue any more with Peter Jarvis, no discussions which would start - "Yes, Peter OK, but ....”. There is only silence and it will remain.

\section{Mark Tennant, Emeritus Professor, University of Technology Sydney, New South Wales, Australia: ${ }^{23}$}

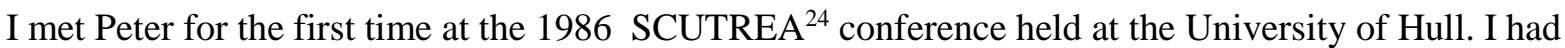
recently published an article in the International Journal of Lifelong Education and Peter was keen to discuss this article and enquire about our adult education courses at the University of Technology Sydney. I said I was grateful for his book Adult and Continuing Education: Theory and practice (Jarvis 1983), which, for me comprised the best introduction to the field available at the time. Meeting Peter was significant for me for a number of reasons. Firstly I enjoyed his company, he seemed to me to revel in what life had to offer and he was always ready to have discussions across a range of topics in philosophy, history, politics, sociology and psychology - and of course the general field of adult education. Secondly, as a commissioning editor for Croom Helm he asked about my future publication intentions. In no time I had two book contracts with Croom Helm: one on the psychology of adult learning and the other an edited book on adult and continuing education in Australia. The first book went on to receive the Houle Award at the AAACE conference in Salt Lake City in 1990 and Peter generously spoke at the award ceremony. Unfortunately I never managed to let him know that, thirty two years later, I am writing a fourth edition of this book. The second book comprised authors from the University of Technology Sydney (UTS); it served to set out some of the programs and practices in adult education in Australia, and it presaged the flurry of research and scholarly work from academics at UTS working in the area of adult education. The Croom Helm series also published books by Stephen Brookfield, Colin Griffin, Sean Courtney, Ettore Gelpi, Huey Long, Chris Duke, Victoria Marsick and Karen Watkins. Peter was clearly a catalyst for the dissemination of research and scholarly work in the field of adult education. Thirdly, Peter was indefatigable with his own writing. Apart from Adult and Continuing Education I have been influenced by some of his earlier books such as Twentieth Century Thinkers in Adult and Continuing Education (Jarvis 1987) and Adult Learning in the Social Context (Jarvis 1987). Significantly he came closer to my own interest in the formation of persons with later works such as Paradoxes of Learning: On becoming an individual in society (Jarvis 1992) and Learning to be a Person in Society (Jarvis 2009). Finally, Peter was always an engaging presence at various international meetings and conferences. He loved his vocation and was a great presenter, influencing scholars and students throughout the world. His joy in scholarly debate was palpable, and his generosity and encouragement to others exceptional.

\section{J.E. (Teddy) Thomas, Robert Peers Professor of Adult Education Emeritus, University of Nottingham, England; founding joint editor with Peter Jarvis of the International Journal of Lifelong Education: ${ }^{25}$}

My first real contact with Peter was when we were planning the publication of the first issue of the International Journal of Lifelong Education in the early 1980s. We were the first joint editors. It took

\footnotetext{
${ }^{23}$ Mark.Tennant@uts.edu.au

${ }^{24}$ Standing Conference on University Teaching and Research in the Education of Adults.

${ }^{25}$ profteddythomas@gmail.com
} 
some courage on the part of publishers to launch a new journal of any sort, especially one of probably limited appeal, but Falmer Press did. There followed a lot of meetings, some of which were extremely convivial, all of which were very productive. And so it was launched. Over the course of the next twenty years or so Peter and I and John Davies, the excellent Reviews Editor met in London, after a short time with Taylor and Francis, ${ }^{26}$ to plan each issue. During this time I came to know Peter well. After each formal meeting we would round off the day in a favourite hostelry, which was not only enjoyable, but very productive since Peter was, as might be expected passionate about the Journal and anxious to make it a success. And so it is. Deciding which articles to publish sounds a rather gloomy business, with huge potential for disagreement, but actually because Peter had such a sense of fun, the whole business was charged with pleasure.

I also saw Peter at work in Surrey University since I became involved in the affairs of his Department, inter alia as external examiner. Here again I saw a truly professional at work. Despite the hideous pressure on staff to publish, Peter was keen to ensure that the students were treated well, and that their University experience would be constructive and memorable: not always a priority amongst University staff it must be said. I also saw Peter present at conferences, and here again serious academic business was leavened with jollity.

I mourn his passing, as many do, but treasure the memory of him.

\section{Sir Alan Tuckett, Professor of Education, University of Wolverhampton; Chief Executive of the National Institute for Adult Continuing Education (1988-2011); President of the International Council for Adult Education (2011-2015): ${ }^{27}$}

The first thing to say about Peter Jarvis was that he was fun. He combined an extraordinary skill in describing in accessible language the key issues at the heart of debates about adult learning, of course, and for that he was admired all over the world, and universally mourned. Because he was a bon viveur, with a delight in travel, food, wine and conversation it would be easy to miss the deeply serious commitment to supporting academic work throughout the developing world. His mission to engage, support, stimulate and explain bubbled out of him, turning his formation as a preacher to our benefit in adult education. My own early engagements with Peter had a significant impact on my work, and that of the National Institute of Adult Continuing Education. As a product of the 'sixties, and active in, then President of, the utopian International League for Social Commitment in Adult Education, I was committed to participatory education to shaping and co-producing research with new literates. In a ten minute conversation, over a characteristic glass of red, Peter convinced me of the complementary power of participation studies - the identification of who isn't there, as a precursor to identifying what can be done about it. Three years later, when I moved to NIACE (the National Institute of Adult Continuing Education) I worked with Naomi Sargant to instigate what has from the mid-1990s been an annual series of participation studies in the UK, complemented by qualitative studies that addressed the issues of how best to serve marginalised communities. Peter's role in triggering that development may have been modest but it was seminal. And wherever II have worked people have similar stories to tell. However, two cameos capture my sense of gratitude and delight in Peter. The first came when he invited me to the University of Surrey to speak at the graduation of

\footnotetext{
26 'Taylor \& Francis acquire[d] Falmer Press, an educational publisher of books and journals based in Brighton' in 1979 (Steele 2013: 16).

${ }^{27}$ Alan.Tuckett@wlv.ac.uk
} 
students on nursing and other professional formation studies. I drove down from Leicester to the event and as I got out of the car at the campus the trousers of my suit split. Quick as a flash and with a wicked smile Peter found an academic gown of the sort you found in 1950s movies, explaining 'that is what they were designed for'. I wore it until safely returned to my car seat. His smile and occasional private joke turned an embarrassment into a Lucky Jim like warm escapade. My second was enjoying Peter bathing in the love and respect of his peers at the dinner the University of Nottingham gave him on the day he was awarded his honorary doctorate there. It was a proper encomium, and his modesty shone through. Finally, I can't resist telling a conversation we had in Bangkok. 'Why doesn't NIACE use me more?', he asked. 'If only we could keep you in the country long enough we would', my colleague replied. But his agenda and achievement were global, developed through teaching and dialogue with scholars and students in more than 90 countries. He was, then, an effective missionary for adult learning, and we will miss him.

\section{Professor Yoko Watanabe, College of Creative Studies, Niigata University, Japan: ${ }^{28}$}

So many memories from his visits to Japan, and from my visits to him in UK: Peter visited Japan three times, which might not be so often for as a frequent a traveller as he, but he left a lot to our adult and lifelong educators, scholars, graduate students, and health professionals. And for me, he has been a great teacher since graduate student years, a great academic to lead me into deep reflection and consideration with a wider perspective, and a heartwarming, thoughtful mentor and nice charming friend.

His first visit was around 1985, when Professor Kosaku Miyasaka, University of Tokyo, invited Peter and Allen Tough from Canada. They ran a symposium together. I was participating in the symposium as a graduate student of Ochanomizu Womens' University. After the session, I was asked to take them to the hotel. We really enjoyed the pleasant conversation in the taxi, and I was so lucky to experience the ride with them.

It was twenty-five years later that I met Peter again. From 2000 to 2017 I was working as an associate professor of lifelong education in Kyoto University's the Graduate School of Education. During that time, my colleague and I published a translation of The Theory and Practice of Teaching (Jarvis 2002) in Japan, and I needed some help in that process. I looked up Peter's e-mail address on the internet and sent him a hopeful e-mail. 'Do you remember me from the taxi in Japan many years ago?' To my great surprise, I heard from him just a few minutes later. He said he remembered me, and was willing to help me. When the translation came out, I invited Peter to visit, and we had several meaningful sessions together. He also attended a student-managed seminar. And when, several days after his return, the Great East Japan Earthquake occurred, Peter promptly sent an e-mail to inquire about our safety. He was especially worried about Machiko Shibahara's family in Iwaki, Fukushima. Machiko was a graduate student who had taken the role of interpreter at his talks. Peter's consideration was always with us. His third visit was to the Department of Pharmacy, Kyoto University, which invited him to monitor and give advice about their education. He attended the IPE session as a guest speaker, too.

We miss him so much, and never forget his dedication and humanity. Now we are working on another translation (of Adult Education and Lifelong Learning, (Jarvis 2010)), which should be published next

\footnotetext{
${ }^{28}$ wyoko@create.niigata-u.ac.jp
} 
year. Peter has given us an awful lot, and will continue to give, too. We would like to turn ourselves from takers to givers in adult and lifelong education field, and we shall dedicate the book to him when it comes to publication. Thank you, Peter, very much.

\title{
Linden West, Professor of Education, Canterbury Christ Church University, England: ${ }^{29}$
}

\author{
In dialogue with Peter Jarvis: past, present and future
}

We go back a long way, Peter and me. To the early 1990s and times of crisis for adult education. Liberal adult education was weakening and derided as a relic of an unfashionable social democracy, out of tune with individualistic Thatcherism and the labour market instrumentalization of education. We used to meet under the umbrella of the aptly named Southern Comfort, an alliance of university adult education departments from Southampton to Kent. Our dialogue was anxious about the future as the old ring-fenced funding for university adult education ended and a world of provision, reaching back long before the 1919 Report (Ministry of Reconstruction, 1919), withered.

Looking back then, from now, I knew little of Peter's background, or his values. I only recently learnt he was born in Gillingham in Kent (Holford, 2017), the county where I live and where I researched learner motivation (West, 1996). I knew but vaguely his Methodist ministry and the early placement in Sheffield, soon to face the tsunami of deindustrialisation. Our dialogue hinted at big issues in adult education and a wider world: of the limits of reason and conventional quantitative research when addressing core aspects of adult learning. And of how biographical perspectives illuminated the poetry, reflexivity, courage, resilience, vulnerability and doubts in learning lives. He worried that Methodism might hold too rationalistic an interpretation of humanity's search for meaning, neglecting the enchantment and even mystery at the heart of religious experience and transformative learning. I glimpsed his working-class desire to travel and engage with others in diverse places; and the centrality of dialogue in his ideas about adult education. Peter's conception of the learning subject was profoundly relational, respectful, I/thou, in Buber's language (Jarvis, 1983/2010).

Later, in the new century, we talked in places like Slovenia and Greece, where I, another workingclass lad, was doing my travels too. We mused on the scientistic reductionism of the academy and the deification of positivistic science and Chicago economics. Here lay a compulsion to generalise and to relieve ourselves of what was seen as the burden of singular instances. But 'truth', we thought, was never an average, and transcendence might be found in whole lives as well as everyday things, like connectedness across difference in an adult class or auto/biographical dialogue. There was, we mused, a place for religious metaphor - once strong in adult education, subsequently derided and lost (Formenti and West, 2018). We touched on emotionality in human flourishing, when we feel seen by someone important to us, and can then see, in psychoanalyst Donald Winnicott's (1971) compelling words. But we did not get far with this and now Peter is gone. Or is he? Our conversation continues as I write these words; illuminating the dynamics of inner and external worlds, materiality and spirituality, self and other in adult education.

\section{References}

${ }^{29}$ linden.west@canterbury.ac.uk 
Formenti, L. and West, L. (2018). Transforming perspectives on lifelong learning and adult education: a dialogue. London: Palgrave Macmillan.

Holford, J. (2017). Local and Global in the formation of a learning theorist: Peter Jarvis and adult education. International Journal of Lifelong Education, 36(1-2), 2-21. https://www.tandfonline.com/doi/full/10.1080/02601370.2017.1299994

Holford, J., Milana, M., Waller, R. \& Webb, S. (eds.) (2018) The Learning Adult: Building and Reflecting on the Work of Peter Jarvis. Abingdon: Routledge.

Jarvis, P. (1983). Adult and Continuing Education: Theory and Practice. Beckenham: Croom Helm.

Jarvis, P. (1985) The Sociology of Adult and Continuing Education. London: Routledge.

Jarvis, P. (1987) Adult Learning in The Social Context. Beckenham: Croom Helm.

Jarvis, P. (1995) Adult \& Continuing Education: Theory and Practice. London: Routledge.

Jarvis, P. (2001) Learning in Later Life: an introduction for educators \& carers. London: Kogan Page.

Jarvis, P. (ed.) (2002) The Theory and Practice of Teaching. London: Kogan Page.

Jarvis, P. (2009) Learning to be a Person in Society. Abingdon: Routledge.

Jarvis, P. (2010) Adult Education and Lifelong Learning: Theory and Practice ( th $^{\text {th }}$ edition). Abingdon: Routledge.

Laksamba, C. (2005) Policy and practice of lifelong learning in Nepal: a socio-political study. Ph.D. thesis, University of Surrey. Available at: http://epubs.surrey.ac.uk/794561/1/Laksamba.pdf

Steele, R. (2013) About Taylor \& Francis, the Academic Division of Informa plc, Editors' Bulletin, 9:1, 13-18, DOI: 10.1080/17521742.2013.870718.

Ministry of Reconstruction (1919). Adult Education Committee: Final Report. Cmd 321. London: HMSO.

West L. (1996). Beyond Fragments. London: Taylor and Francis.

Winnicott, D. (1971). Playing and reality. London: Routledge. 